BNL-113279-2016-JA

\title{
Hydricity, Electrochemistry, and Excited-State Chemistry of Ir Complexes for CO2 Reduction
}

\author{
Gerald F. Manbeck, Komal Garg, Tomoe Shimoda, David J. Szalda, \\ Mehmed Z. Ertem, James T. Muckerman, and Etsuko Fujita
}

Submitted to Faraday Discussions

December 2016

Chemistry Department

Brookhaven National Laboratory

\author{
U.S. Department of Energy \\ USDOE Office of Science (SC), \\ Basic Energy Sciences (BES) (SC-22)
}

Notice: This manuscript has been authored by employees of Brookhaven Science Associates, LLC under Contract No. DE- SC0012704 with the U.S. Department of Energy. The publisher by accepting the manuscript for publication acknowledges that the United States Government retains a non-exclusive, paid-up, irrevocable, world-wide license to publish or reproduce the published form of this manuscript, or allow others to do so, for United States Government purposes. 


\section{DISCLAIMER}

This report was prepared as an account of work sponsored by an agency of the United States Government. Neither the United States Government nor any agency thereof, nor any of their employees, nor any of their contractors, subcontractors, or their employees, makes any warranty, express or implied, or assumes any legal liability or responsibility for the accuracy, completeness, or any third party's use or the results of such use of any information, apparatus, product, or process disclosed, or represents that its use would not infringe privately owned rights. Reference herein to any specific commercial product, process, or service by trade name, trademark, manufacturer, or otherwise, does not necessarily constitute or imply its endorsement, recommendation, or favoring by the United States Government or any agency thereof or its contractors or subcontractors. The views and opinions of authors expressed herein do not necessarily state or reflect those of the United States Government or any agency thereof. 


\title{
Hydricity, Electrochemistry, and Excited-State Chemistry of Ir Complexes for $\mathrm{CO}_{2}$ Reduction
}

\author{
Gerald F. Manbeck* ${ }^{\dagger}$, Komal Garg ${ }^{\dagger}$, Tomoe Shimoda ${ }^{\dagger}$, David J. Szalda ${ }^{*}$, \\ Mehmed Z. Ertem*,†, James T. Muckerman ${ }^{\dagger}$ and Etsuko Fujita*, ${ }^{\dagger}$ \\ ${ }^{\dagger}$ Chemistry Division, Brookhaven National Laboratory, Upton, NY 11973-5000, USA \\ $\$$ Department of Natural Science, Baruch College, CUNY, New York, New York 10010, \\ USA
}

\begin{abstract}
We prepared electron-rich derivatives of $[\operatorname{Ir}(\operatorname{tpy})(\mathrm{ppy}) \mathrm{Cl}]^{+}$with modification of the bidentate (ppy) or tridentate (tpy) ligands in an attempt to increase the reactivity for $\mathrm{CO}_{2}$ reduction and the ability to transfer hydrides (hydricity). Density functional theory (DFT) calculations reveal that complexes with dimethyl-substituted ppy have similar hydricities to the non-substituted parent complex, and photocatalytic $\mathrm{CO}_{2}$ reduction studies show selective CO formation. Substitution of tpy by bis(benzimidazole)-phenyl or -pyridine (L3 and L4, respectively) induces changes in the physical properties much more pronounced than from the addition of methyl groups to ppy. Theoretical data predict $[\operatorname{Ir}(\mathrm{L} 3)(\mathrm{ppy})(\mathrm{H})]$ is the strongest hydride donor among complexes studied in this work, but $\left[\operatorname{Ir}(\mathrm{L} 3)(\mathrm{ppy})\left(\mathrm{NCCH}_{3}\right)\right]^{+}$cannot be reduced photochemically because the excited state reduction potential is only $0.52 \mathrm{~V}$ due to the negative ground-state potential of $-1.91 \mathrm{~V}$. The excited state $\left[\operatorname{Ir}(\mathrm{L} 4)(\mathrm{ppy})\left(\mathrm{NCCH}_{3}\right)\right]^{2+}$ is the strongest oxidant among complexes studied in this work and the singly-reduced species is formed readily upon photolysis in the presence of tertiary amines. Both $\left[\operatorname{Ir}(\mathrm{L} 3)(\mathrm{ppy})\left(\mathrm{NCCH}_{3}\right)\right]^{+}$and $\left[\operatorname{Ir}(\mathrm{L} 4)(\mathrm{ppy})\left(\mathrm{NCCH}_{3}\right)\right]^{2+}$ exhibit electrocatalytic current for $\mathrm{CO}_{2}$ reduction. While a significantly greater overpotential is needed for the L3 complex, a small amount of formate $(5-10 \%)$ generation in addition to $\mathrm{CO}$ was observed as predicted by the DFT calculations.
\end{abstract}

\section{Introduction}

Transition-metal hydrides play crucial roles in the hydrogenation/dehydrogenation of organic substrates including $\mathrm{CO}_{2}$, formate and methanol, $\mathrm{H}_{2}$ production/oxidation, transfer hydrogenation, olefin isomerization, etc. ${ }^{1,2}$ The hydricity, i.e., hydride-transfer ability, is an important thermodynamic property together with the acidity, i.e., protontransfer ability for the design of catalysts, especially for fuel generation reactions. While the hydricities of metal hydrides have been experimentally and theoretically determined in $\mathrm{CH}_{3} \mathrm{CN}$, ${ }^{1,3,4}$ recently solvent effects on the hydricity have been investigated in water ${ }^{5-8}$ and $\mathrm{DMF}^{8} \mathrm{~A}$ comparison between the hydricity of metal-H and its dihydrogen (to produce a proton) and/or formate (to produce $\mathrm{CO}_{2}$ ) reveals a narrowing in the range of values and an increasing hydricity strength with increasing solvent polarity. 
An efficient photocatalytic system with $[\mathbf{I r}-\mathrm{Cl}]^{+}\left(\mathbf{I r}=\operatorname{Ir}(\operatorname{tpy})(\mathrm{ppy})\right.$, tpy $=2,2^{\prime}: 6^{\prime}, 2^{\prime \prime}-$ terpyridine, ppy $=2$-phenylpyridine) and triethanolamine (TEOA) in $\mathrm{CH}_{3} \mathrm{CN}$ has been reported to selectively reduce $\mathrm{CO}_{2}$ to $\mathrm{CO}$ under visible light $(410<\lambda<750 \mathrm{~nm})$ with a TON of 38 and quantum yield $\left(\Phi_{\mathrm{CO}}\right)$ of 0.13 . ${ }^{9}$ Because the hydride species was proposed as an important intermediate, we have isolated two isomers of $[\mathbf{I r}-\mathrm{H}]^{+}$, where the hydride is trans to either $\mathrm{N}$ of ppy $\left(\mathrm{N}\right.$-trans- $\left.[\mathbf{I r}-\mathrm{H}]^{+}\right)$or to $\mathrm{C}$ of ppy $\left(\mathrm{C}\right.$-trans- $\left.[\mathbf{I r}-\mathrm{H}]^{+}\right)$and have studied their distinct reactivity in the ground and excited states. ${ }^{10} \mathrm{~N}$-trans-[$[\mathbf{I r}-\mathrm{H}]^{+}$that has a ${ }^{1} \mathrm{H}$ NMR chemical shift at $-19.3 \mathrm{ppm}$ is more stable than the other isomer, and does not react with $\mathrm{CO}_{2}$ owing to its weak observed and computed hydricity of 57 and 53.7 kcal $\mathrm{mol}^{-1}$ respectively, in $\mathrm{CH}_{3} \mathrm{CN}$. C-trans- $[\mathbf{I r}-\mathrm{H}]^{+}$, which has a ${ }^{1} \mathrm{H}$ NMR chemical shift at $-7.46 \mathrm{ppm}$ and a computed hydricity of $43.2 \mathrm{kcal} \mathrm{mol}^{-1}$, reacts with $\mathrm{CO}_{2}$ to form [Ir$\mathrm{OCHO}^{+}$in the ground state. However, this hydride is a photo-acid that can produce the five-coordinate $C$-trans-[ $\left[\mathbf{I r}^{0}\right]$ upon photoexcitation. While $\mathrm{N}$-trans- $[\mathbf{I r}-\mathrm{H}]^{+}$was a proposed key intermediate in the photochemical $\mathrm{CO}_{2}$ reduction to $\mathrm{CO}$ with $[\mathbf{I r}-\mathrm{Cl}]^{+}$, we found that $C$-trans- $\left[\mathbf{I r}^{0}\right]$ is the common intermediate in pathways starting with $N$-trans$[\mathbf{I r}-\mathrm{H}]^{+}, \mathrm{C}$-trans- $[\mathbf{I r}-\mathrm{H}]^{+}$and $\mathrm{C}$-trans- $[\mathbf{I r}-\mathrm{Cl}]^{+}{ }^{10}$ In order to obtain stronger hydride donors to go beyond formate or $\mathrm{CO}$ for the reduction of $\mathrm{CO}_{2}$ via hydride transfer reactions, we have explored several Ir complexes with more electron-donating ligands. Unfortunately, we found that the strongest hydride donor suggested by theoretical calculations could not be experimentally characterized owing to its high reactivity. Here we report the electrochemistry, excited-state properties, photocatalytic $\mathrm{CO}_{2}$ reduction, and computed values of the hydricity of these Ir complexes shown in Figure 1 with ligands L1-L4.

\section{Results and Discussion}

Synthesis and Characterization. The cyclometalation reactions of L1 and L2 with $\left[\operatorname{Ir}(\right.$ tpy $\left.) \mathrm{Cl}_{3}\right]$ were promoted in ethylene glycol at $200{ }^{\circ} \mathrm{C} .{ }^{11}$ The L3 complexes $[\operatorname{Ir}(\mathrm{L} 3)(\mathrm{ppy}) \mathrm{Cl}]$ and $\left[\operatorname{Ir}(\mathrm{L} 3)(\mathrm{ppy})\left(\mathrm{NCCH}_{3}\right)\right]^{+}$have been reported previously and were obtained in this work with spectral data in agreement with literature. ${ }^{12}$ The $\left[\operatorname{Ir}(\mathrm{L} 4)(\mathrm{ppy})\left(\mathrm{NCCH}_{3}\right)\right]^{2+}$ was prepared from $[\operatorname{Ir}(\mathrm{L} 4)(\mathrm{ppy}) \mathrm{Cl}]^{+}$by treatment with $\mathrm{AgPF}_{6}$ in $\mathrm{CH}_{3} \mathrm{CN}$. We performed complete characterization on the known complexes since available literature data are reported in different solvents and the photo- or electrocatalytic reactions were not discussed. ${ }^{12}$ In each complex, the isomer with $\mathrm{Cl}^{-}$or $\mathrm{CH}_{3} \mathrm{CN}$ ligand trans to $\mathrm{C}$ of ppy or ppy derivatives was isolated consistent with computed free energies which favor trans to $\mathrm{C}$ isomers by $5-18 \mathrm{kcal} \mathrm{mol}^{-1}$ depending on the identity of the complex and the ligand (see below, Table 3).

Crystals of $\left[\operatorname{Ir}(\mathrm{L} 3)\left(\right.\right.$ ppy)Cl] $\cdot \mathrm{NCCH}_{3}$ were grown by diffusion of ether into a $\mathrm{CH}_{3} \mathrm{CN}$ solution and an ORTEP diagram of the structure is presented in Figure 1. The structure of $[\operatorname{Ir}(\mathrm{L} 3)(\mathrm{ppy}) \mathrm{Cl}]$ is very similar to that of $[\operatorname{Ir}(\mathrm{L} 3)(\mathrm{mppy}) \mathrm{Cl}]$ (mppy = 2-(4methylphenyl)pyridine) that was previously reported. ${ }^{12}$ The only minor differences between $[\operatorname{Ir}(\mathrm{L} 3)(\mathrm{ppy}) \mathrm{Cl}]$ and $[\operatorname{Ir}(\mathrm{L} 3)(\mathrm{mppy}) \mathrm{Cl}]$ are the solvents of crystallization and that the coordinated chloride is only $0.087 \AA$ out of the best plane of the ppy in $[\operatorname{Ir}(\mathrm{L} 3)(\mathrm{ppy}) \mathrm{Cl}]$ while it is $0.361 \AA$ out of the best plane of mppy in [ $\operatorname{Ir}(\mathrm{L} 3)(\mathrm{mppy}) \mathrm{Cl}]$. This may be a result of the dihedral angle between the two rings of the ppy being 1.92 degrees in $[\operatorname{Ir}(\mathrm{L} 3)(\mathrm{ppy}) \mathrm{Cl}]$ and 5.31 degrees in [ $\operatorname{Ir}(\mathrm{L} 3)(\mathrm{mppy}) \mathrm{Cl}]$. 

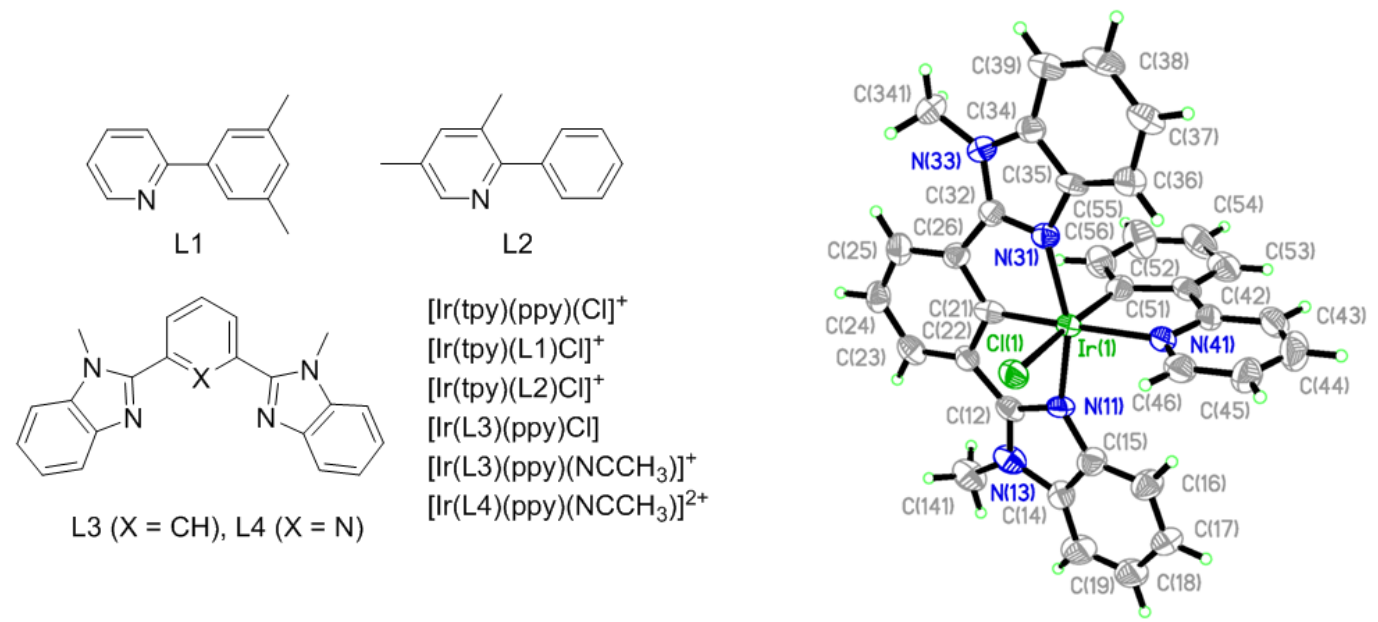

Figure 1. Ligands and Ir complex nomenclature used in this paper. The cyclometalated phenyl ligand loses a proton upon coordination. The crystal structure of $[\mathrm{Ir}(\mathrm{L} 3)(\mathrm{ppy}) \mathrm{Cl}] \cdot \mathrm{CH}_{3} \mathrm{CN}$ with $50 \%$ probability ellipsoids omitting $\mathrm{CH}_{3} \mathrm{CN}$ of crystallization is also shown.

Electrochemistry. The redox properties of five Ir complexes were studied by cyclic or square wave voltammetry in $\mathrm{Ar}$ - or $\mathrm{CO}_{2}$-saturated $\mathrm{CH}_{3} \mathrm{CN}$ (Figure 2 and Table 1). The reductive $\mathrm{CV}$ of each terpyridyl complex features a reversible couple at ca. $-1.05 \mathrm{~V}$ SCE and an irreversible or quasi-reversible couple at -1.25 or $-1.28 \mathrm{~V}$. Previous work suggested assignment of these redox processes as tpy ${ }^{0 /-}$ and $\mathrm{ppy}^{0 /-}$ reductions for related chloro complexes ${ }^{13,14}$ on the basis of $\left[\operatorname{Ir}(\mathrm{bpy})(\mathrm{ppy})_{2}\right]^{+}$-type complexes. ${ }^{15}$ Our data suggest, however, that the second yields a species with substantial $\operatorname{Ir}(\mathrm{I})$ character. First, the peak separation of $\sim 0.2 \mathrm{~V}$ is much smaller than the $0.6 \mathrm{~V}$ reported for $\left[\operatorname{Ir}(\mathrm{bpy})(\mathrm{ppy})_{2}\right]^{+}$-type complexes ${ }^{15}$ and suggest charge compensation by chloride anion dissociation after the first reduction. Second, transient absorption data in the presence of a reductive quencher reveal a rapid unimolecular process that is tentatively assigned to dissociation of $\mathrm{Cl}^{-}$from the singly reduced complexes (see below). The $\mathrm{Cl}^{-}$dissociation yields a five-coordinate species or a solvent bound complex that could be reduced at less negative potentials than the singly reduced chloro complex. Third, calculations of the doubly reduced species reveal substantial $\operatorname{Ir}(\mathrm{I})$ character. Finally, the catalysis of $\mathrm{CO}_{2}$ reduction as triggered by the second reduction is evidence of $\operatorname{Ir}(\mathrm{I})$ character in the doubly reduced complexes.

In the presence of $\mathrm{CO}_{2}$ and $5 \%$ water as a proton source, significant catalytic current is observed at the second reduction couple in agreement with an earlier report. ${ }^{11}$ The halfwave potential of the catalytic wave is $-1.2 \mathrm{~V}$, and current increases at negative potentials where the tpy ligand can be reduced again. The small separation between the first and second reductions facilitates formation of the doubly reduced species under photocatalytic conditions in the absence of an exogenous photosensitizer (see below).

The $\left[\operatorname{Ir}(\mathrm{L} 3)(\mathrm{ppy})\left(\mathrm{NCCH}_{3}\right)\right]^{+}$complex is reduced irreversibly at $-1.91 \mathrm{~V}$. The current at this wave is $\sim 1.7$ times the current of a fully reversible oxidation at $1.21 \mathrm{~V}$, but less than the $2^{3 / 2}$ factor expected of a two-electron wave. At elevated scan rates, a re-oxidation wave is observed with $\Delta E_{\mathrm{p}} \sim 70-90 \mathrm{mV}$. Based on these observations, we assign the first 
reduction of the L3 complex according to an ECE mechanism, in which the fast electrochemical step (likely $\mathrm{CH}_{3} \mathrm{CN}$ dissociation) is followed by the second reduction with a standard potential slightly cathodic of the first couple. Under $\mathrm{CO}_{2}$, a catalytic current is triggered by the first reduction wave and offers further evidence of twoelectron reduction since catalysis of $\mathrm{CO}_{2}$ chemistry by singly reduced metal complexes is rare (although not impossible). ${ }^{16}$ The computed $1 \mathrm{e}^{-}$reduction potentials at M06 level of theory for the ECE mechanism are -1.83 and $-1.93 \mathrm{~V}$ and the $2 \mathrm{e}^{-}$reduction potential is $-1.95 \mathrm{~V}$ in quite good agreement with the experimental observations.

The $\mathrm{CV}$ of $\left[\operatorname{Ir}(\mathrm{L} 4)(\mathrm{ppy})\left(\mathrm{NCCH}_{3}\right)\right]^{2+}$ shows a reversible couple at $-0.96 \mathrm{~V}$ and a quasireversible couple at $-1.37 \mathrm{~V}$ which are well-reproduced by computations as well $(-0.93$ and $-1.38 \mathrm{~V})$. The relative ease of reduction in this complex compared to the cyclometalated L3 complex is mainly attributed to the difference in charge of the complexes. The computed Mulliken spin densities in the one electron reduced species for L3 and L4 complexes display similar properties supporting the argument that the shift in reduction potentials mainly stem from the change in overall charges of the complexes. In the presence of $\mathrm{CO}_{2}$, a catalytic current is observed coincident with the second reduction having a half wave potential of $c a .-1.2 \mathrm{~V}$ with a significantly lower overpotential compared to $\left[\operatorname{Ir}(\mathrm{L} 3)(\mathrm{ppy})\left(\mathrm{NCCH}_{3}\right)\right]^{+}$. The current enhancement in the presence of $\mathrm{CO}_{2}$ as a substrate is $\sim 2$ and a new wave at $-1.05 \mathrm{~V}$ is observed upon reoxidation, suggesting the possible oxidation of a catalytic intermediate such as an Ir-CO species.
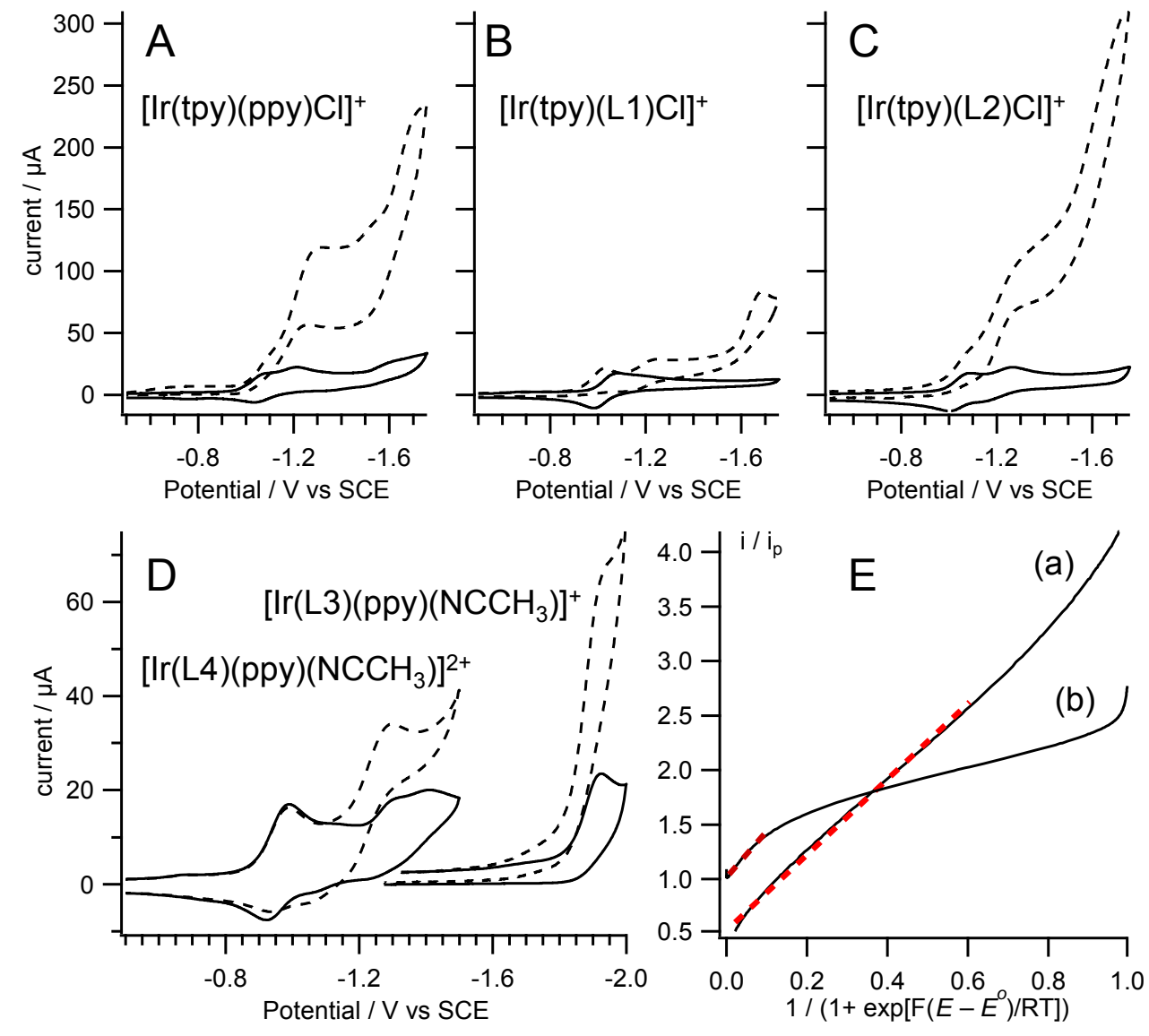
Figure 2. (A-D) Cyclic voltammetry in room temperature $\mathrm{CH}_{3} \mathrm{CN}$ with $0.1 \mathrm{mM} \mathrm{Bu}_{4} \mathrm{NPF}_{6}$ at a glassy carbon working electrode under $\mathrm{Ar}$ (solid) or $\mathrm{CO}_{2}$ (dashed) saturation with $v=$ $0.1 \mathrm{~V} \mathrm{~s}^{-1}$. In A-C data were collected with $5 \%$ water by volume. (E) Foot-of-the wave analysis of plot $\mathrm{D}$ for the electrocatalytic $\mathrm{CO}_{2}$ reduction current of $\left[\operatorname{Ir}(\mathrm{L} 3)(\text { ppy })\left(\mathrm{NCCH}_{3}\right)\right]^{+}$(a) and $\left[\operatorname{Ir}(\mathrm{L} 4)(\text { ppy })\left(\mathrm{NCCH}_{3}\right)\right]^{2+}$ (b) with $v=1 \mathrm{~V} \mathrm{~s}^{-1}$.

The catalytic current observed for L3 and L4 complexes is first order in both catalyst and $\mathrm{CO}_{2}$ concentration. In order to compare the rates of catalysis, $\mathrm{CVs}$ recorded at $1 \mathrm{~V} \mathrm{~s}^{-1}$ were analyzed by the foot-of-the-wave (FOW) method in which the deactivation effects such as decomposition or substrate inhibition are precluded from the kinetic calculation (Figure 2E). ${ }^{17}$ The FOW function for $\left[\operatorname{Ir}(\mathrm{L} 3)(\mathrm{ppy})\left(\mathrm{NCCH}_{3}\right)\right]^{+}$is linear over a large range, demonstrating adherence to ideal behavior, while the curve of $\left[\operatorname{Ir}(\mathrm{L} 4)(\mathrm{ppy})\left(\mathrm{NCCH}_{3}\right)\right]^{2+}$ is linear at positive potentials prior to the current plateau in Figure 2D. Rate constants of $170 \mathrm{M}^{-1} \mathrm{~s}^{-1}$ and $260 \mathrm{M}^{-1} \mathrm{~s}^{-1}$ for the L3 and L4 complexes, respectively, were derived from the slopes shown in red in Figure 2E.

Bulk electrolysis experiments of $[\operatorname{Ir}(\mathrm{L} 3)(\mathrm{ppy}) \mathrm{Cl})]$ and $[\operatorname{Ir}(\mathrm{L} 4)(\mathrm{ppy}) \mathrm{Cl}]^{+}$were performed for product analysis and quantification. The applied potential was at the maximum current of the catalytic wave for the corresponding $\mathrm{CH}_{3} \mathrm{CN}$ complexes, since both precursors will yield the same catalyst during electrolysis. The $[\operatorname{Ir}(\mathrm{L} 4)(\mathrm{ppy}) \mathrm{Cl}]^{+}$produced $\mathrm{CO}$ with quantitative Faradaic efficiency, while $[\operatorname{Ir}(\mathrm{L} 3)(\mathrm{ppy}) \mathrm{Cl})]$ yielded $\mathrm{CO}$ with a charge efficiency of $45 \pm 5 \%$ and formate with an efficiency of 5-10\%. Neither complex produced $\mathrm{H}_{2}$ upon electrolysis. As detailed below, the production of formate is supported by theoretical data that show the L3 C-trans hydride as the most hydridic compound among both isomers of all five Ir complexes. The theoretical data show that if the hydride forms by the reaction of a doubly-reduced species with residual water, $\mathrm{CO}_{2}$ insertion to yield formate is feasible. The cause of low charge efficiency is unclear as no other gaseous or liquid phase products were detectable. NMR analysis of the solution after electrolysis of ${ }^{13} \mathrm{CO}_{2}$ revealed only formate and carbonate. Carbonate is a minor component and is typically formed by a mechanism in which $\mathrm{CO}_{2}$ acts as the oxide acceptor to yield a metal carbonyl species prior to dissociation of $\mathrm{CO}$. While the applied potential of $-1.9 \mathrm{~V}$ is considerably negative, the $\mathrm{Hg}$ electrode was not active for $\mathrm{CO}_{2}$ reduction under these conditions and minimal current was consumed in a blank experiment.

Photophysical properties. Absorption and emission spectra for each complex are shown in Figure 3 and the data are summarized in Table 1. The absorption spectra $[\operatorname{Ir}(\operatorname{tpy})(\mathrm{L} 1) \mathrm{Cl}]^{+}$and $[\operatorname{Ir}(\operatorname{tpy})(\mathrm{L} 2) \mathrm{Cl}]^{+}$are similar and feature broad, low energy, bands at ca $550 \mathrm{~nm}$ which have been assigned as spin-forbidden ${ }^{3}$ MLCT absorptions in related complexes. $^{11}$ In the UV region, several prominent bands are observed and detailed assignments have been provided elsewhere with support from TD-DFT calculations. ${ }^{13}$ To summarize, the highest occupied molecular orbitals are composed of Ir d orbitals mixed with $\pi$ orbitals of the phenyl ligand, while the lowest unoccupied molecular orbitals are localized on tpy. The low energy bands are dominated by mixed MLCT/ILCT transitions while higher energy bands arise from intraligand $\pi \rightarrow \pi^{*}$ and interligand $\pi \rightarrow \pi^{*}$ or $n \rightarrow \pi^{*}$ transitions. The UV-vis spectra of $[\operatorname{Ir}(\mathrm{L} 3)(\mathrm{ppy}) \mathrm{Cl}], \quad\left[\operatorname{Ir}(\mathrm{L} 3)(\mathrm{ppy})\left(\mathrm{NCCH}_{3}\right)\right]^{+}$and $\left[\operatorname{Ir}(\mathrm{L} 4)(\mathrm{ppy})\left(\mathrm{NCCH}_{3}\right)\right]^{2+}$ feature intense low energy bands from $375-425 \mathrm{~nm}$ that are 
progressively blue-shifted with substitution of $\mathrm{CH}_{3} \mathrm{CN}$ for $\mathrm{Cl}^{-}$and of $\mathrm{L} 4$ for $\mathrm{L} 3$. In chloro complexes, the HOMO is Ir- $\mathrm{d}+\mathrm{Cl}(3 \mathrm{p})$, while in $\mathrm{CH}_{3} \mathrm{CN}$ complexes it is comprised of $\mathrm{Ir}$ $\mathrm{d}+$ phenyl $\pi$ orbitals. ${ }^{12}$ The blue-shifted absorption in the $\mathrm{CH}_{3} \mathrm{CN}$ complex is consistent with stabilization of the HOMO due to delocalization and back bonding. In complexes of $\mathrm{L} 3$, the LUMO is delocalized over the L3 $\pi$-orbitals while the LUMO of L4 complexes is localized on a pyridyl-benzimidazole moiety, consistent with the blue-shifted absorption. ${ }^{12}$

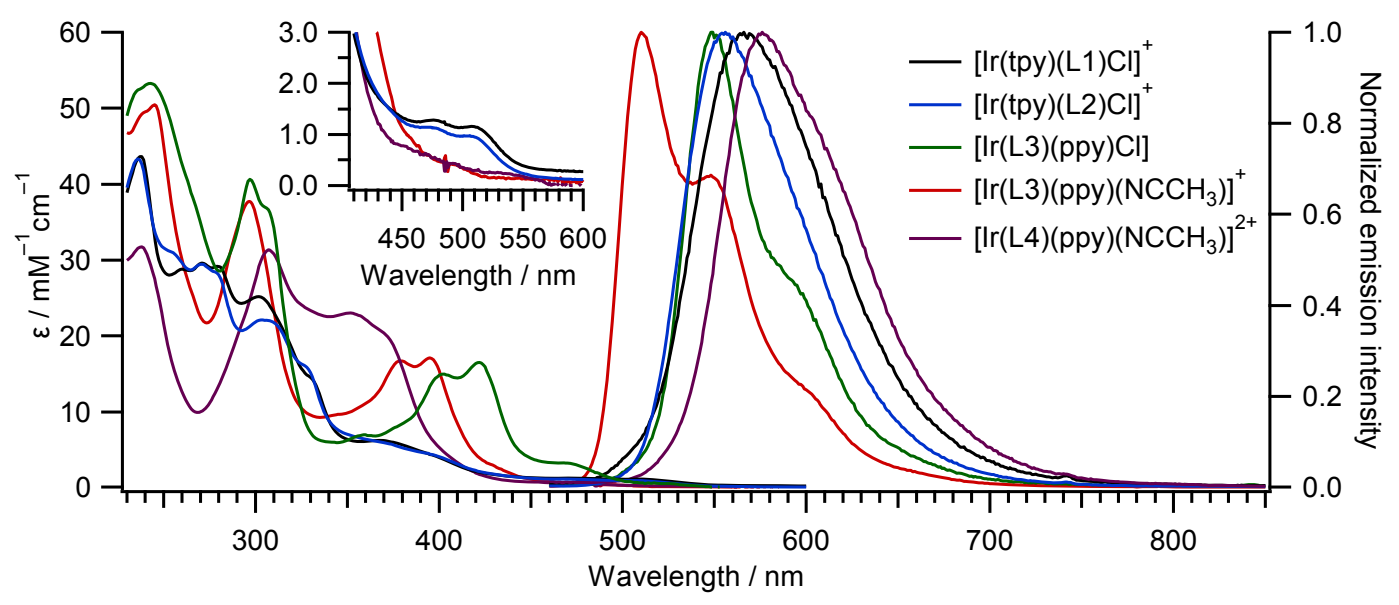

Figure 3. Absorption and emission spectra of $\mathrm{Ir}$ complexes in $\mathrm{CH}_{3} \mathrm{CN}$ at room temperature. The inset is an expansion of the visible region probed during photocatalysis. See Tables 1 and 2.

The Ir complexes were all prepared with the intent for use as photocatalysts for $\mathrm{CO}_{2}$ reduction under visible-light irradiation. Thus it is useful to compare the integrated absorptivities, $\Psi$, for $\lambda>410 \mathrm{~nm}$ (Table 1). Although the value of $\Psi$ for $[\operatorname{Ir}(\mathrm{L} 3)(\mathrm{ppy}) \mathrm{Cl}]$ is largest, and $\Psi$ for $\left[\operatorname{Ir}(\mathrm{L} 3)(\mathrm{ppy})\left(\mathrm{NCCH}_{3}\right)\right]^{+}$is comparable to the $[\operatorname{Ir}(\mathrm{tpy})(\mathrm{ppy}) \mathrm{Cl}]^{+}$ family; the L3 complexes cannot function as photocatalysts owing to their weakly oxidizing excited states (Table 1). The $\left[\operatorname{Ir}(\mathrm{L} 3)(\mathrm{ppy})\left(\mathrm{NCCH}_{3}\right)\right]^{2+}$ complex absorbs poorly in the visible region, which could be a factor in its low photocatalytic reactivity (see below). 
Table 1. UV-vis and electrochemical data in $\mathrm{CH}_{3} \mathrm{CN}$.

\begin{tabular}{|c|c|c|c|c|}
\hline Complex & $\lambda_{\max } / \mathrm{nm}\left(\varepsilon, \mathrm{mM}^{-1} \mathrm{~cm}^{-1}\right)$ & $\begin{array}{c}\Psi^{\mathrm{a}} / \\
\mathrm{M}^{-1} \mathrm{~cm}^{-2}\end{array}$ & $E / \mathrm{V}$ vs SCE & $\begin{array}{l}E^{\mathrm{n}+* /(\mathrm{n}-1)^{+}} / \\
\text {V vs SCE }\end{array}$ \\
\hline$[\operatorname{Ir}(\operatorname{tpy})(\mathrm{L} 1) \mathrm{Cl}]^{+}$ & 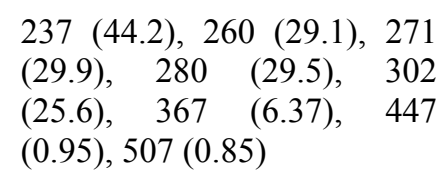 & 195 & $\begin{array}{l}1.57,,^{b}-1.05,-1.25, b \\
-1.92\end{array}$ & 1.14 \\
\hline$[\operatorname{Ir}(\operatorname{tpy})(\mathrm{L} 2) \mathrm{Cl}]^{+}$ & $\begin{array}{l}2236(43.5), 270(29.3), 304 \\
(22.1), \quad 472 \quad(1.02), \quad 505 \\
(0.870) .\end{array}$ & 173 & $\begin{array}{l}1.64,{ }^{\mathrm{b}}-1.06,-1.28 \\
-1.93\end{array}$ & 1.17 \\
\hline$[\operatorname{Ir}(\mathrm{L} 3)(\mathrm{ppy}) \mathrm{Cl}]$ & $\begin{array}{l}243(50.9), 297(39.0), 402 \\
(14.3), 422(15.8)\end{array}$ & 613 & $-2.01,-2.35^{\mathrm{c}}$ & 0.25 \\
\hline$\left[\operatorname{Ir}(\mathrm{L} 3)(\mathrm{ppy})\left(\mathrm{NCCH}_{3}\right)\right]^{+}$ & $\begin{array}{l}245(50.9), 296(38.5), 380 \\
(17.1), 394(17.6)\end{array}$ & 183 & $\begin{array}{l}1.21,-1.91,{ }^{\mathrm{d}}-2.19, \\
-2.38^{\mathrm{b}}\end{array}$ & 0.52 \\
\hline$\left[\operatorname{Ir}(\mathrm{L} 4)(\mathrm{ppy})\left(\mathrm{NCCH}_{3}\right)\right]^{2+}$ & $\begin{array}{l}238(31.7), 307(31.3), 350 \\
(23.0)\end{array}$ & 104 & $-0.96,-1.37$ & 1.2 \\
\hline
\end{tabular}

${ }^{\mathrm{a}}$ Integrated absorptivity for $\lambda>410 \mathrm{~nm}\left(E<24390 \mathrm{~cm}^{-1}\right) \cdot{ }^{\mathrm{b}}$ Quasi-reversible or irreversible couple. The potentials for quasireversible or irreversible couples were measured by OSWV. ${ }^{c}$ Data from the literature. ${ }^{12 \mathrm{~d}}$ Two overlapping one-electron reductions presumably connected via an ECE mechanism. A return wave for the first couple is observed at $v>750 \mathrm{mV} \mathrm{s}^{-1}$. ${ }^{\mathrm{e}}$ Excited state reduction potential calculated from $E^{\mathrm{oo}}+E^{\mathrm{n}+/(\mathrm{n}-1)+}$.

Each complex exhibits intense, long-lived emission in fluid solution with quantum yields of 0.12-0.41 and lifetimes of 870-2790 ns (Table 2). Excitation spectra show good agreement with absorption spectra. The emission of $[\operatorname{Ir}(\operatorname{tpy})(\mathrm{L} 1) \mathrm{Cl}]^{+}$is slightly redshifted relative to that of $[\operatorname{Ir}(\mathrm{tpy})(\mathrm{L} 2) \mathrm{Cl}]^{+}$with a lower lifetime and quantum yield and an increased $k_{\mathrm{nr}}$, which are consistent with expectations based on energy gap arguments. Since the LUMO is unchanged (as indicated by identical $[\mathrm{Ir}]^{+/ 0}$ potentials), the red shift is attributed to destabilization of the HOMO by the inductive effect of the dimethyl substitution because the phenyl $\pi$ orbitals are more strongly mixed with $\mathrm{Ir}$ in the HOMO compared to the pyridyl $\pi$ orbitals. The relative emission energies for complexes of L3 and $\mathrm{L} 4$ in $\mathrm{CH}_{3} \mathrm{CN}$ are found in agreement with literature data ${ }^{12}$ in $\mathrm{CH}_{2} \mathrm{Cl}_{2}$. The new complex, $\left[\operatorname{Ir}(\mathrm{L} 4)(\mathrm{ppy})\left(\mathrm{NCCH}_{3}\right)\right]^{2+}$, exhibits emission properties consistent with the trends discussed previously. ${ }^{12}$ Notably, the low-energy emission and long-lived excited states are inconsistent with the L3 complexes due to the lower rate of radiative decay. The mechanism of phosphorescence was discussed in detail in previous work by Obara et al. ${ }^{12}$ To summarize, the small $k_{\mathrm{r}}$ of L4 complexes is due to the localization of the LUMO on half of the L4 ligand. Consequently, poor mixing with the ppy $\pi$ orbitals yields a lower oscillator strength for the singlet state and a large energy gap between the $T_{1}$ state and the $\mathrm{S}_{\mathrm{n}}$ state that must mix with $\mathrm{T}_{1}$ for spin-orbit coupling induced radiative decay. At $77 \mathrm{~K}$, emission maxima are blue-shifted relative to the room temperature data and strong vibronic resolution is observed with progression of $1000-1400 \mathrm{~cm}^{-1}$. The $\lambda_{\max }$ at $77 \mathrm{~K}$ was used to estimate the triplet excited state energy, $E^{\mathrm{oo}}$, needed to calculate the excited state reduction potential. 
Table 2. Photophysical data in air-free $\mathrm{CH}_{3} \mathrm{CN}$ at $293 \mathrm{~K}$ or butyronitrile glass at $77 \mathrm{~K}$.

\begin{tabular}{lccccccc}
\hline \multicolumn{1}{c}{ Complex } & \multicolumn{2}{c}{$\lambda_{\max }^{\mathrm{em}} / \mathrm{nm}$} & \multicolumn{2}{c}{$\tau_{\mathrm{em}} / \mu \mathrm{s}$} & $\Phi_{\mathrm{em}}^{\mathrm{b}}$ & $\begin{array}{c}\mathrm{k}_{\mathrm{r}} / 10^{5} \\
\mathrm{k}_{\mathrm{nr}} / 10^{5}\end{array}$ \\
& $293 \mathrm{~K}$ & $77 \mathrm{~K}$ & $293 \mathrm{~K}$ & $77 \mathrm{~K}$ & & $\mathrm{~s}^{-1 \mathrm{c}}$ & $\mathrm{s}^{-1 \mathrm{c}}$ \\
\hline$[\operatorname{Ir}(\mathrm{tpy})(\mathrm{L} 1) \mathrm{Cl}]^{+}$ & 567 & 540,580 & 0.87 & 29 & 0.17 & 1.9 & 9.5 \\
{$[\operatorname{Ir}(\mathrm{tpy})(\mathrm{L} 2) \mathrm{Cl}]^{+}$} & 555 & 537,570 & 1.4 & 48 & 0.25 & 1.8 & 5.5 \\
{$[\operatorname{Ir}(\mathrm{L} 3)(\mathrm{ppy}) \mathrm{Cl}]$} & 548,588 & 535,575 & 2.0 & 2.8 & $0.59^{\mathrm{a}}$ & 2.8 & 2.0 \\
{$\left[\operatorname{Ir}(\mathrm{L} 3)(\mathrm{ppy})\left(\mathrm{NCCH}_{3}\right)\right]^{+}$} & $510,548,602$ & 500,540 & 1.1 & 3.6 & 0.41 & 3.9 & 5.6 \\
{$\left[\operatorname{Ir}(\mathrm{L} 4)(\mathrm{ppy})\left(\mathrm{NCCH}_{3}\right)\right]^{2+}$} & 575 & 545,587 & 2.8 & 13 & 0.12 & 0.43 & 3.2 \\
\hline
\end{tabular}

${ }^{\mathrm{a}}$ Reference $12 .{ }^{\mathrm{b}}$ Determined using $\left[\mathrm{Ru}(\mathrm{bpy})_{3}\right]^{2+}$ as a standard. ${ }^{\mathrm{c}} \Phi=k_{\mathrm{r}} /\left(k_{\mathrm{r}}+k_{\mathrm{nr}}\right)=\tau \times k_{\mathrm{r}}$

Transient absorption and reductive quenching. Transient absorption spectroscopy provides a means to verify the excited state assignments provided in the literature according to DFT calculations. Figure 4 shows the excited state difference spectra of the five Ir complexes $200 \mathrm{~ns}$ after laser excitation at $355 \mathrm{~nm}$. The spectra of the tpy complexes reveal broad excited state absorptions at 380, which would overlap with any ground state ${ }^{1}$ MLCT bleach in this region, and at $560 \mathrm{~nm}$ and $\lambda>680 \mathrm{~nm}$. The lowenergy absorptions are consistent with tpy ligand $\pi \rightarrow \pi^{*}$ states and resemble those observed in $\left[\operatorname{Ir}(\mathrm{NCN})(\text { tpy) }]^{2+}\right.$ derivatives ${ }^{18}$ and $\mathrm{Pt}(\mathrm{II})$ terpyridyl acetylides. ${ }^{19}$ Absorptions for $\lambda<400 \mathrm{~nm}$ are also assigned to transitions associated with the reduced terpyridine ligand as shown by the similarity between the excited state difference spectrum and the one-electron reduced spectrum obtained by reductive quenching with $\mathrm{Et}_{3} \mathrm{~N}$. Figure 5 shows the spectrum of the singly reduced species and the kinetic trace monitored at 400 $\mathrm{nm}$. Quenching rates with $\mathrm{Et}_{3} \mathrm{~N}$ are 1.2 and $1.8 \times 10^{9} \mathrm{M}^{-1} \mathrm{~s}^{-1}$ for L1 and L2 complexes, respectively, consistent with the slightly higher driving force for reductive quenching using $[\operatorname{Ir}(\mathrm{tpy})(\mathrm{L} 2)(\mathrm{Cl})]^{+}$. Within the first $0.5 \mu \mathrm{s}$, the entire spectrum decays rapidly due to excited state quenching; however, in the region of the $400 \mathrm{~nm}$ absorbance, an increase in $\Delta \mathrm{Abs}$ is observed on a longer timescale with single exponential kinetics (3.2 $\mu$ s for L1 and $2.1 \mu \mathrm{s}$ for L2). The spectral features do not evolve except for an increase in oscillator strength of the $400 \mathrm{~nm}$ band. The final spectrum persists for several hundred milliseconds. We assign the observed increase in $\Delta \mathrm{Abs}$ to rapid loss of the chloride ligand, consistent with the small separation between the first and second reductions as discussed above.

Excited state difference spectra of each L3 and L4 complex show a ground state bleach of the lowest-energy ${ }^{1}$ MLCT or ${ }^{1}$ MLCT+ILCT absorption. Spectra of [ $\left.\operatorname{Ir}(\mathrm{L} 3)(\mathrm{ppy}) \mathrm{Cl}\right]$ and $\left[\operatorname{Ir}(\mathrm{L3})(\text { ppy })\left(\mathrm{NCCH}_{3}\right)\right]^{+}$exhibit intense absorptions in the $\mathrm{UV}$ at $330 \mathrm{~nm}$ and broad bands at 540 and $660 \mathrm{~nm}$. The spectral features of $[\operatorname{Ir}(\mathrm{L} 3)(\mathrm{ppy}) \mathrm{Cl}]$ in the midvisible (550$600 \mathrm{~nm})$ are partially obscured by over-correction of the intense photoluminescence. Nevertheless, the 330 and $660 \mathrm{~nm}$ absorptions are reasonably similar and suggest absorptions centered on the formally reduced L3 ligand with little influence on the nature of the hole $\left(\mathrm{Ir}+\mathrm{Cl}\right.$ in $[\operatorname{Ir}(\mathrm{L} 3)(\mathrm{ppy}) \mathrm{Cl}]$ or $\mathrm{Ir}+$ phenyl in $\left[\operatorname{Ir}(\mathrm{L} 3)(\mathrm{ppy})\left(\mathrm{NCCH}_{3}\right)\right]^{+}$. The excited states of L3 complexes are weak oxidants, and it was not possible to obtain spectra of the singly-reduced species by reductive quenching. Furthermore, the first reduction of these complexes occurs by an ECE mechanism with overlapping formal 
potentials, and the singly reduced species could not be obtained by chemical reduction with sodium amalgam.

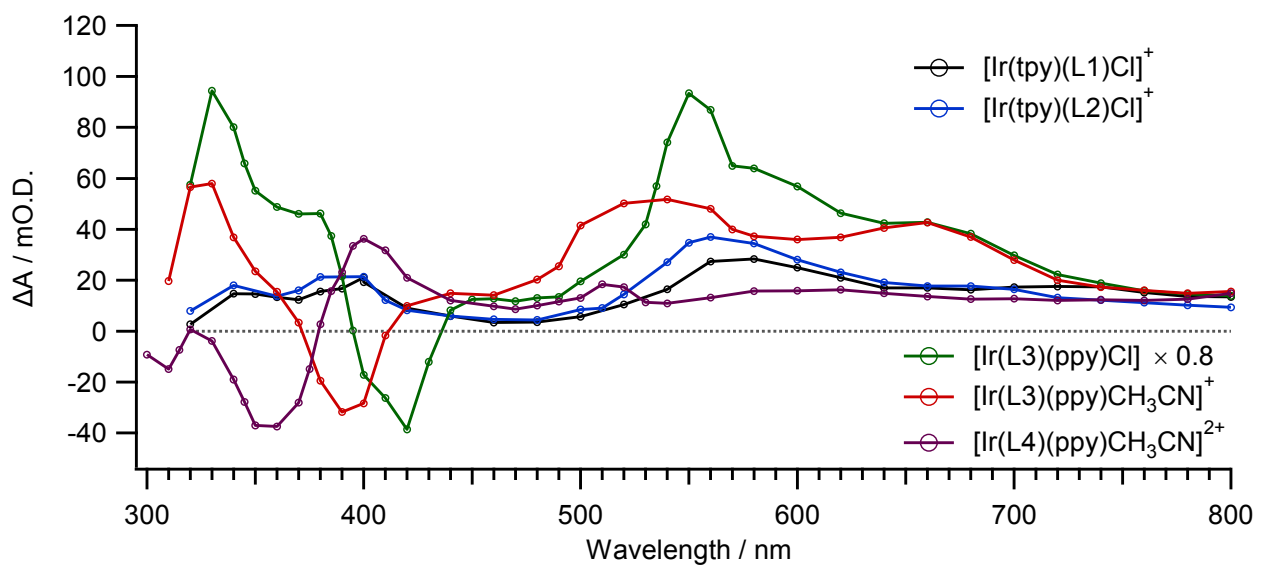

Figure 4. Excited state difference spectra for Ir complexes in $\mathrm{CH}_{3} \mathrm{CN} 200$ ns after the laser pulse. The peaks at 550 and 580 in the spectrum of $[\operatorname{Ir}(\mathrm{L} 3)(\mathrm{ppy}) \mathrm{Cl}]$ are due to slight over-correction of the intense photoluminescence.

(A)

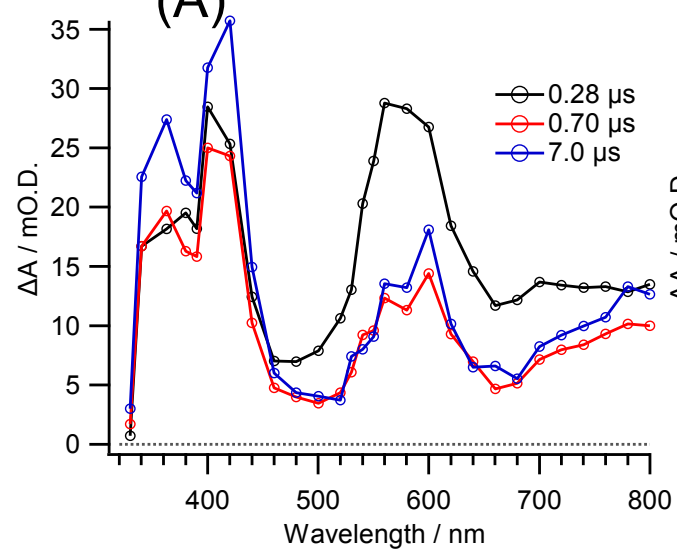

(B)

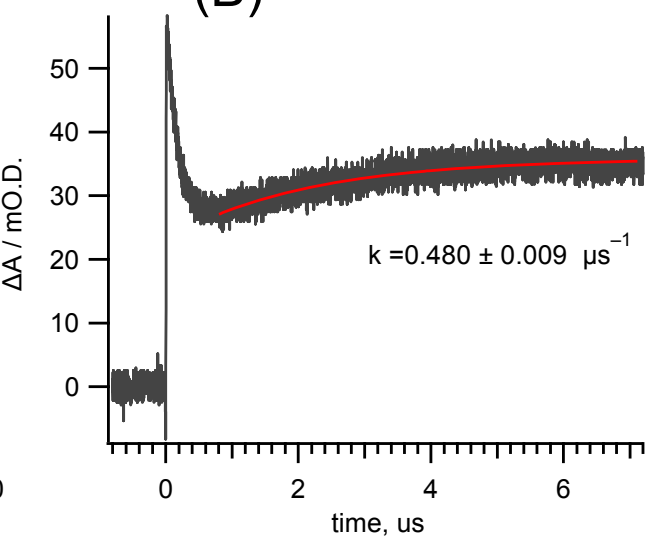

Figure 5. (A) Difference spectrum of the singly reduced $[\operatorname{Ir}(\operatorname{tpy})(\mathrm{L} 2)]^{+}$obtained by reductive quenching followed by proposed loss of $\mathrm{Cl}^{-}$with $k=4.8 \times 10^{5} \mathrm{~s}^{-1}$ according to the fit of the kinetic trace at $400 \mathrm{~nm}(\mathrm{~B})$.

The excited state difference spectrum of $\left[\operatorname{Ir}(\mathrm{L} 4)(\mathrm{ppy})\left(\mathrm{NCCH}_{3}\right)\right]^{2+}$ is drastically different from the L3 complexes. There is a strong absorption at $400 \mathrm{~nm}$, which is absent in the L3 complexes, a narrow band at $510 \mathrm{~nm}$, and a broad absorption centered at $620 \mathrm{~nm}$. Interestingly, the features at 400 and $510 \mathrm{~nm}$ are qualitatively similar to those of the $\mathrm{Ir} \rightarrow$ bpy $\pi^{*}{ }^{3}$ MCLT state of photoexcited $\left[\operatorname{Ir}(\text { ppy })_{2}(\text { bpy })\right]^{+}$in which the absorptions were assigned to the reduced bpy ligand. ${ }^{20}$ The similar nature confirms the localization of the excited state in $\left[\operatorname{Ir}(\mathrm{L} 4)(\mathrm{ppy})\left(\mathrm{NCCH}_{3}\right)\right]^{2+}$ on a pyridyl-benzimidazole unit as suggested in the literature as opposed to a formal anion localized over the entire L4. The excited state was quenched by $\mathrm{Et}_{3} \mathrm{~N}\left(k_{\mathrm{Q}}=1.3 \times 10^{9} \mathrm{M}^{-1} \mathrm{~cm}^{-1}\right)$ and the singly reduced complex features a strong absorption at $410 \mathrm{~nm}$ in agreement with the excited state. Slow ground 
state reactivity with $\mathrm{Et}_{3} \mathrm{~N}$ was observed (presumably ligand exchange), and rapid quenching necessitated averaging of only a few kinetic traces. Therefore, the spectral features above $400 \mathrm{~nm}$ were not clearly resolved.

Hydride complexes. We performed density functional theory (DFT) calculations to predict the relative stability and hydricity of $C$-trans and $N$-trans hydride isomers of all the complexes in $\mathrm{CH}_{3} \mathrm{CN}$. Firstly, $\mathrm{N}$-trans hydrides were found to be more stable than $\mathrm{C}$ trans isomers by $4-6 \mathrm{kcal} \mathrm{mol}^{-1}$ for all complexes except L3 for which the C-trans isomer is favored by $4.1 \mathrm{kcal} \mathrm{mol}^{-1}$ (Table 3 ). The computed structures at the M06 level of theory display shorter Ir-H bond lengths (1.60-1.62 $\AA$ ) for $N$-trans hydrides compared to those of $C$-trans isomers (1.69-1.72 $\AA$ ) as expected due to stronger trans influence in the latter. Next we computed hydricities of the complexes relative to the $\left[\mathrm{Ru}^{\text {II }} \text { (tpy)(bpy)H }\right]^{+} /\left[\mathrm{Ru}^{\mathrm{II}}(\mathrm{tpy})(\mathrm{bpy})\left(\mathrm{NCCH}_{3}\right)\right]^{2+}$ couple for which the experimental hydricity is known $\left(\Delta G_{\mathrm{H}^{-}}^{\circ}=39 \pm 3 \mathrm{kcal} \mathrm{mol}^{-1}\right){ }^{7}$ The computed hydricities for L1, L2 and $\mathrm{L} 4$ are quite similar to $[\operatorname{Ir}(\text { tpy })(\text { bpy }) \mathrm{H}]^{+}$analogues (Table 4$)$. Although we could not isolate $N$-trans or $C$-trans-[ $\operatorname{Ir}(\mathrm{L} 3)(\mathrm{ppy}) \mathrm{H}]$ experimentally, likely due to high reactivity, L3 complexes display significantly stronger hydride donor capability for both isomers compared to the other complexes with $\Delta G^{\circ}{ }_{\mathrm{H}^{-}}=47.3$ and $37.1 \mathrm{kcal} \mathrm{mol}{ }^{-1}$ for $N$-trans and $C$-trans-[Ir(L3)(ppy)H] respectively. As a next step we considered the hydride transfer by the complexes to $\mathrm{CO}_{2}$ to generate the formato adduct and predicted $C$-trans hydrides to be more reactive consistent with the calculated hydricities (Table 4). Although the $C$ trans-[Ir(L3)(ppy)H] has the lowest computed hydricity $(6.1 \mathrm{kcal} / \mathrm{mol}$ lower than $C$ trans- $\left.[\operatorname{Ir}(\operatorname{tpy})(\mathrm{ppy}) \mathrm{H}]^{+}\right)$, the free energy change for the formation of the formato adduct is quite similar to other $C$-trans hydrides (Table 4) which indicate that the ground state reactivity toward $\mathrm{CO}_{2}$ is expected to be similar for all $\mathrm{C}$-trans hydrides. We isolated $\mathrm{N}$ trans-[Ir(tpy)(L1)H] $]^{+}(\mathrm{Ir}-\mathrm{H}$ at $-18.7 \mathrm{ppm})$ and C-trans-[Ir(tpy)(L1)H] $]^{+}(-9.63 \mathrm{ppm})$ and carried out the $\mathrm{CO}_{2}$ insertion reaction in the dark. Only C-trans-[Ir(tpy)(L1)H]$]^{+}$reacted with $\mathrm{CO}_{2}$, consistent with the calculated hydricity value of $44.6 \mathrm{kcal} \mathrm{mol}^{-1}$ vs $56.7 \mathrm{kcal}$ $\mathrm{mol}^{-1}$ for the $N$-trans species.

Table 3. Computed relative free energies $\left(\Delta G^{\circ}\right)$ in units of kcal mol ${ }^{-1}$ for $N$-trans complexes with respect to $C$-trans isomers at the $\operatorname{Ir}($ III) oxidation state.

\begin{tabular}{|c|c|c|c|c|}
\hline \multirow[b]{2}{*}{ Complex } & \multicolumn{4}{|c|}{$\begin{array}{c}\text { Relative Free Energies }\left(\Delta G^{\circ}\right) \text { for } \\
N \text {-trans complexes with respect to C-trans }\end{array}$} \\
\hline & MeCN & $\mathrm{Cl}^{-}$ & $\mathbf{H}^{-}$ & $\mathrm{HCO}_{2}$ \\
\hline $\operatorname{Ir}($ tpy)(ppy) & 6.1 & 8.1 & -4.4 & 7.6 \\
\hline $\operatorname{Ir}(t p y)(L 1)$ & 5.7 & 10.4 & -6.3 & 8.1 \\
\hline $\operatorname{Ir}($ tpy $)(L 2)$ & 8.6 & 7.4 & -4.2 & 8.3 \\
\hline Ir(L3)(ppy) & 14.2 & 17.8 & 4.1 & 16.6 \\
\hline $\operatorname{Ir}(\mathbf{L} 4)(\mathbf{p p y})$ & 5.5 & 7.6 & -6.0 & 5.8 \\
\hline
\end{tabular}


Table 4. Computed hydricities $\left(\Delta G^{\circ} \mathrm{H}^{-}\right)$and free energy changes for $\mathrm{CO}_{2}$ insertion $\left(\Delta G^{\circ} \mathrm{CO} 2 / \mathrm{HCO}_{2}\right)$ reactions for $N$-trans and $C$-trans hydride complexes.

\begin{tabular}{ccccc}
\hline & \multicolumn{2}{c}{$\begin{array}{c}\text { Computed Hydricities } \\
\left(\Delta G^{\circ} \mathrm{H}^{-}\right)\end{array}$} & $\begin{array}{c}\text { Free Energy Changes for } \mathrm{CO}_{2} \\
\text { Insertion }\left(\Delta G_{\mathrm{CO} 2}^{\circ} / \mathrm{HCO}_{2}-\right)\end{array}$ \\
\hline Complex & $\boldsymbol{N}$-trans-[Ir-H] & $\boldsymbol{C}$-trans-[Ir-H] & $\boldsymbol{N}$-trans-[Ir-H] & $\boldsymbol{C}$-trans-[Ir-H] \\
\hline $\mathbf{I r}(\mathbf{t p y})(\mathbf{p p y})$ & 53.7 & 43.2 & 11.9 & -0.1 \\
$\mathbf{I r}(\mathbf{t p y})(\mathbf{L 1})$ & 56.7 & 44.6 & 15.1 & 0.7 \\
$\mathbf{I r}(\mathbf{t p y})(\mathbf{L 2})$ & 56.6 & 43.8 & 14.3 & 1.8 \\
$\mathbf{I r}(\mathbf{L 3})(\mathbf{p p y})$ & 47.3 & 37.1 & 12.7 & 0.2 \\
$\mathbf{I r}(\mathbf{L 4})(\mathbf{p p y})$ & 53.8 & 42.3 & 12.6 & 0.8 \\
\hline
\end{tabular}

Photocatalytic $\mathrm{CO}_{2}$ reduction. As described above, $\mathrm{CVs}$ of $[\operatorname{Ir}(\mathrm{tpy})(\mathrm{L} 1) \mathrm{Cl}]^{+}$and $[\operatorname{Ir}(\operatorname{tpy})(\mathrm{L} 2) \mathrm{Cl}]^{+}$under $\mathrm{Ar}$ and $\mathrm{CO}_{2}$ are quantitatively similar to those of $\left[\operatorname{Ir}(\right.$ tpy $)(\text { ppy)Cl }]^{+9,10}$ indicating that the doubly-reduced, five-coordinate species react with $\mathrm{CO}_{2}$. Photocatalytic $\mathrm{CO}_{2}$ reduction was tested under visible light irradiation $(>400$ $\mathrm{nm}$ ) in the presence of the sacrificial electron donor TEOA. Under these conditions, the catalysts were active for reduction of $\mathrm{CO}_{2}$ to $\mathrm{CO}$ for approximately 2 hours. The $[\operatorname{Ir}(\operatorname{tpy})(\mathrm{ppy}) \mathrm{Cl}]^{+}$and $[\operatorname{Ir}(\operatorname{tpy})(\mathrm{L} 2) \mathrm{Cl}]^{+}$showed identical activity with 37 and 36 total turnovers, respectively, while $[\operatorname{Ir}(\mathrm{tpy})(\mathrm{L} 1) \mathrm{Cl}]^{+}$yielded only 13 turnovers of $\mathrm{CO}$. This result is consistent with the comparatively low catalytic current observed in the $\mathrm{CV}$ of $[\operatorname{Ir}(\text { tpy })(\mathrm{L} 1) \mathrm{Cl}]^{+}$. Each new tpy complex showed greater than 20:1 CO: $\mathrm{H}_{2}$ selectivity. The photo-production of $\mathrm{CO}$ was linear for each catalyst for at least 30 minutes, and the maximum quantum yield of photocatalysis can be estimated after 30 minutes of irradiation. Upon irradiation with a monochromatic $405 \mathrm{~nm}$ diode laser, the parent $\left[\operatorname{Ir}(\operatorname{tpy})(\text { ppy)Cl}]^{+}\right.$exhibited the highest $\Phi_{\mathrm{CO}}$ of $24 \pm 3 \%$ while $[\operatorname{Ir}(\operatorname{tpy})(\mathrm{L} 1) \mathrm{Cl}]^{+}$and $[\operatorname{Ir}(\mathrm{tpy})(\mathrm{L} 2) \mathrm{Cl}]^{+}$were less efficient $(3.7 \pm 0.2$ and $11.4 \pm 0.2 \%$, respectively). Although the final turnover numbers of $[\operatorname{Ir}(\operatorname{tpy})(\mathrm{ppy}) \mathrm{Cl}]^{+}$and $[\operatorname{Ir}(\operatorname{tpy})(\mathrm{L} 2) \mathrm{Cl}]^{+}$are identical, the unsubstituted ppy complex produced $\mathrm{CO}$ most rapidly and most efficiently before evolution of $\mathrm{CO}$ ceased. Photocatalytic activity with [Ir(L3)(ppy)Cl] or $\left[\operatorname{Ir}(\mathrm{L} 3)(\mathrm{ppy})\left(\mathrm{NCCH}_{3}\right)\right]^{+}$was not observed because the excited state of the complex cannot be quenched reductively. Photocatalytic $\mathrm{CO}_{2}$ reduction using $\left[\operatorname{Ir}(\mathrm{L} 4)(\mathrm{ppy})\left(\mathrm{NCCH}_{3}\right)\right]^{2+}$ produced $\mathrm{CO}$ with a TON of 12 and a quantum yield of $2.6 \pm 0.3 \%$ ) along with a small amount of $\mathrm{H}_{2}\left(\Phi_{\mathrm{H} 2}=0.5 \%\right)$ An almost negligible amount of formate $(\mathrm{TON}<1)$ was obtained, consistent with the electrochemical results that showed complete selectivity for $\mathrm{CO}$ and with the computed hydricity of $N$-trans- $[\operatorname{Ir}(\mathrm{L} 4)(\mathrm{ppy})(\mathrm{H})]^{+}$, being thermodynamically incapable of reducing $\mathrm{CO}_{2}$ to formate even if the hydride species forms during the reaction. Factors responsible for inefficient catalysis using $\left[\operatorname{Ir}(\mathrm{L} 4)(\text { ppy })\left(\mathrm{NCCH}_{3}\right)\right]^{2+}$ might include the low visible light absorptivity, inefficient double reduction via excitation/quenching or the reaction with the TEOA radical cation, product inhibition by the formation of unreactive carbonyl or carboxylate complexes, ${ }^{21}$ or decomposition of the singly reduced complex. This catalysts clearly performs better under electrochemical vs. photochemical conditions for $\mathrm{CO}_{2}$ reduction to $\mathrm{CO}$. 


\section{Conclusions}

The complex $\left[\operatorname{Ir}(\text { tpy)(ppy)Cl] }]^{+}\right.$is one of the few molecular complexes capable of photochemical $\mathrm{CO}_{2}$ reduction without the necessity of an additional photosensitizer because the complex itself is capable of light absorption, oxidation of a sacrificial reagent, and multielectron catalysis of the reduction of $\mathrm{CO}_{2}$ to $\mathrm{CO}$. Guided by known mechanistic principles of this family of complexes, we prepared electron-rich derivatives with modification of the bidentate (ppy) or tridentate (tpy) ligands in attempt to increase the reactivity, as measured by turnover rates or turnover numbers, or the donor ability of hydrides, as shown by a possible change in mechanism favoring formate production or further reduced products. Theoretical data reveal similar hydricities among [Ir(tpy)(ppyL1-L2)Cl] ${ }^{+}$derivatives and the photochemical reaction remained selective for $\mathrm{CO}$ formation. While the $[\operatorname{Ir}(\mathrm{tpy})(\mathrm{L} 2) \mathrm{Cl}]^{+}$retained similar activity to the parent ppy complex, the $[\operatorname{Ir}(\operatorname{tpy})(\mathrm{L} 1) \mathrm{Cl}]^{+}$showed significantly lower reactivity in photo- or electrocatalysis suggesting that the electron rich cyclometalated ligand might deter catalysis by decreasing the thermodynamics or kinetics of product release.

Substitution of tpy for bis(benzimidazole)-phenyl or -pyridine (L3 and L4, respectively) induces changes in the physical properties much more pronounced than addition of methyl groups to ppy. The excited state $\left[\operatorname{Ir}(\mathrm{L} 4)(\mathrm{ppy})\left(\mathrm{NCCH}_{3}\right)\right]^{2+}$ is the strongest oxidant among complexes studied in this work and the singly reduced species is formed readily upon photolysis in the presence of tertiary amines. Despite the facile photoreduction, the photo-catalytic reduction of $\mathrm{CO}_{2}$ is limited, possibly due to inefficient double reduction during photolysis or instability of the singly-reduced species during irradiation. In contrast, $\left[\operatorname{Ir}(\mathrm{L} 3)(\mathrm{ppy})\left(\mathrm{NCCH}_{3}\right)\right]^{+}$cannot be reduced photochemically because the excited state reduction potential is only $0.52 \mathrm{~V}$ due to the very negative ground state potential of $-1.91 \mathrm{~V}$. Both $\left[\operatorname{Ir}(\mathrm{L} 3)(\mathrm{ppy})\left(\mathrm{NCCH}_{3}\right)\right]^{+}$and $\left[\operatorname{Ir}(\mathrm{L} 4)(\mathrm{ppy})\left(\mathrm{NCCH}_{3}\right)\right]^{2+}$ exhibit electrocatalytic current for $\mathrm{CO}_{2}$ reduction. While the L4 complex is catalytic at $-1.2 \mathrm{~V}$, a significantly greater overpotential is needed for the L3 complex. Product quantification revealed that the L4 complex is selective for CO, while the L3 complex forms formate (5-10\%) with CO. This observation is supported by theoretical data that show the L3 C-trans hydride as the most hydridic compound among both isomers of all five Ir complexes studied in this work demonstrating that if the hydride forms by the reaction of a doubly-reduced species with residual water, $\mathrm{CO}_{2}$ insertion to yield formate is thermodynamically favorable.

\section{Experimental Section}

Materials. $\mathrm{CH}_{3} \mathrm{CN}$ for spectroscopic measurements was pre-dried over an activated alumina column and further dried over molecular sieves activated at $350^{\circ} \mathrm{C}$ and stored inside a glove box. The complexes $\left[\operatorname{Ir}\left(\mathrm{L}_{3}\right) \mathrm{Cl}_{2}\right]_{2}, \quad\left[\operatorname{Ir}(\mathrm{L} 4) \mathrm{Cl}_{3}\right], \quad[\operatorname{Ir}(\mathrm{L} 3)(\mathrm{ppy}) \mathrm{Cl}]$, $\left[\operatorname{Ir}(\mathrm{L} 3)(\mathrm{ppy})\left(\mathrm{NCCH}_{3}\right)\right] \mathrm{OTf}$ and $[\operatorname{Ir}(\mathrm{L} 4)(\mathrm{ppy}) \mathrm{Cl}] \mathrm{PF}_{6}$ were prepared according to the previously reported literature procedures ${ }^{12,22}$ with the minor difference of isolation of $\left[\operatorname{Ir}(\mathrm{L} 3)(\text { ppy })\left(\mathrm{NCCH}_{3}\right)\right]^{+}$as the $\mathrm{PF}_{6}$ salt in the current work. Ligands $\mathrm{L}^{23}$ and $\mathrm{L}^{24}$ are known compounds and were prepared by Suzuki coupling. The ligands L3 ${ }^{22,25}$ and L4 ${ }^{26}$ were prepared according to the literature. 
Synthesis of $\left[\operatorname{Ir}(\operatorname{tpy})(\mathbf{L 1}) \mathrm{Cl} \mathbf{P F}_{6}\right.$ and $[\operatorname{Ir}(\operatorname{tpy})(\mathbf{L 2}) \mathbf{C l}] \mathbf{P F}_{6}$. Both $[\operatorname{Ir}(\operatorname{tpy})(\mathrm{L} 1) \mathrm{Cl}] \mathrm{PF}_{6}$ and $[\operatorname{Ir}(\mathrm{tpy})(\mathrm{L} 2) \mathrm{Cl}] \mathrm{PF}_{6}$ were prepared by the method used for $\left[\operatorname{Ir}(\operatorname{tpy})(\mathrm{ppy}) \mathrm{Cl}_{1} \mathrm{PF}_{6}\right.$ by the reaction of $\left[\operatorname{Ir}(\mathrm{tpy}) \mathrm{Cl}_{3}\right.$ ] and a either $\mathrm{L} 1$ or L2. ${ }^{11}{ }^{1} \mathrm{H}$ NMR spectroscopy confirmed the formation of the C-trans isomer in both complexes.

$[\operatorname{Ir}(\mathrm{tpy})(\mathrm{L} 1) \mathrm{Cl}] \mathrm{PF}_{6}:{ }^{1} \mathrm{H}$ NMR $\left(\mathrm{CD}_{3} \mathrm{CN}, 25^{\circ} \mathrm{C}\right): \delta 10.03(\mathrm{~d}, 1 \mathrm{H}, J=5.2), 8.49(\mathrm{~d}, 2 \mathrm{H}, J=$ $8.0), 8.39$ (d, $2 \mathrm{H}, J=8.0), 8.32(\mathrm{t}, 1 \mathrm{H}, J=8.0) 8.31(\mathrm{~d}, 1 \mathrm{H}, J=8.0), 8.16(\mathrm{dt}, 1 \mathrm{H}, J=8.0$, 1.6), 8.079 (dt, $2 \mathrm{H}, J=8.0,1.6), 7.61-7.56(\mathrm{~m}, 4 \mathrm{H}), 7.42(\mathrm{dt}, 2 \mathrm{H}, J=6.2,1.2), 2.22$, s, $3 \mathrm{H}), 1.37(\mathrm{~s}, 3 \mathrm{H}) .{ }^{13} \mathrm{C} \mathrm{NMR}\left(\mathrm{CD}_{3} \mathrm{CN}, 25^{\circ} \mathrm{C}\right): \delta 168.2$ (q), 160.1 (q), 157.9 (q), 153.0, $152.4,146.25$ (q), 145.4 (q), 141.5, 141.3, 141.2, 135.3 (q), 135.0, 134.2 (q), 130.0, 126.9, 125.3, 125.2, 125.1, 122.2, 22.5, 20.7. MS (ESI+): $m / z$ 642.1 (M-PF $)^{+}$.

$[\operatorname{Ir}(\mathrm{tpy})(\mathrm{L} 2) \mathrm{Cl}] \mathrm{PF}_{6}:{ }^{1} \mathrm{H}$ NMR $\left(\mathrm{CD}_{3} \mathrm{CN}, 25^{\circ} \mathrm{C}\right): \delta 9.23(\mathrm{~s}, 1 \mathrm{H}), 8.52(\mathrm{~d}, 2 \mathrm{H}, J=8.0), 8.39-$ $8.33(\mathrm{~m}, 3 \mathrm{H}), 8.07$ (dt, 2H, $J=7.8,1.4), 7.97(\mathrm{~d}, 1 \mathrm{H}, J=8.0), 7.87(\mathrm{~s}, 1 \mathrm{H}), 7.64(\mathrm{~d}, 2 \mathrm{H}, J$ $=4.8), 7.40(\mathrm{dt}, 2 \mathrm{H}, J=6.8,1.6), 6.93(\mathrm{dt}, 1 \mathrm{H}, J=7.6,1.2), 6.70(\mathrm{dt}, 1 \mathrm{H}, J=7.4,1.2)$, $6.06(\mathrm{dd}, 1 \mathrm{H}, J=7.6,1.2), 2.89(\mathrm{~s}, 3 \mathrm{H}), 2.54(\mathrm{~s}, 3 \mathrm{H}) .{ }^{13} \mathrm{C} \mathrm{NMR}\left(\mathrm{CD}_{3} \mathrm{CN}, 25^{\circ} \mathrm{C}\right): \delta 162.4$ (q), 159.5 (q), 156.9 (q), 153.1, 150.6, 147.1 (q), 145.6, 142.8 (q), 141.5, 141.3, 135.0 (q), 134.7 (q), 131.9, 130.3, 129.9, 129.7, 126.9, 125.4, 125.1. MS (ESI+): $\mathrm{m} / \mathrm{z} 643.0$ $\left(\mathrm{M}-\mathrm{PF}_{6}\right)^{+}$.

Synthesis of $\left[\mathbf{I r}(\mathbf{L 4})(\mathbf{p p y})\left(\mathbf{N C C H}_{3}\right)\right]\left(\mathbf{P F}_{\mathbf{6}}\right)_{2}$ : The reaction of $[\operatorname{Ir}(\mathrm{L} 4)(\mathrm{ppy}) \mathrm{Cl}] \mathrm{PF}_{6}$ with $\mathrm{AgPF}_{6}$ in $\mathrm{CH}_{3} \mathrm{CN}$ yielded the title complex. ${ }^{12}{ }^{1} \mathrm{H} \mathrm{NMR}\left(\mathrm{CD}_{3} \mathrm{CN}, 25^{\circ} \mathrm{C}\right): \delta 9.79(\mathrm{~d}, 1 \mathrm{H}, J$ $=5.6), 8.66(\mathrm{~d}, 2 \mathrm{H}, J=8.4), 8.51(\mathrm{t}, 1 \mathrm{H}, J=8.8), 8.43-8.36(\mathrm{~m}, 2 \mathrm{H}), 7.82(\mathrm{dt}, 1 \mathrm{H}, J=6.6$, 1.2), 7.74-7.70 (m, 3H), $7.54(\mathrm{t}, 2 \mathrm{H}, J=7.6), 7.22(\mathrm{t}, 2 \mathrm{H}, J=8.0), 6.90(\mathrm{t}, 2 \mathrm{H}, J=7.6)$, $6.79(\mathrm{t}, 2 \mathrm{H}, J=7.6), 6.11(\mathrm{~d}, 2 \mathrm{H}, J=8.0), 6.00(\mathrm{~d}, 1 \mathrm{H}, J=8.0), 4.46(\mathrm{~s}, 6 \mathrm{H}) .{ }^{13} \mathrm{C}$ NMR $\left(\mathrm{CD}_{3} \mathrm{CN}, 25^{\circ} \mathrm{C}\right): \delta 168.2(\mathrm{q}), 154.4(\mathrm{q}), 153.7,151.2(\mathrm{q}), 145.5(\mathrm{q}), 143.5,142.8,140.1$, 137.0 (q), 136.2 (q), 132.7, 131.9, 128.3, 128.1, 126.3, 126.0, 125.9, 122.7, 116.2, 114.4, 34.2. $\mathrm{MS}(\mathrm{ESI}+): \mathrm{m} / \mathrm{z} 703.1\left(\mathrm{M}-2 \mathrm{PF}_{6}-\mathrm{CH}_{3} \mathrm{CN}+\mathrm{OH}^{-}\right)^{+}$.

Instrumentation and measurements: UV-vis spectra were measured on an Agilent 8453 spectrophotometer. ${ }^{1} \mathrm{H}$ and ${ }^{13} \mathrm{C}$ NMR spectra were collected on a $400 \mathrm{MHz}$ Bruker UltraShield spectrometer in $\mathrm{CD}_{3} \mathrm{CN}$. Chemical shifts in ppm are referenced to the solvent peaks. Electrospray mass spectra (ESI-MS) were measured using a Thermo Finnigan mass spectrometer. Samples for transient absorption and lifetime measurements were prepared with optical densities $<1$ for $\lambda>320 \mathrm{~nm}$ and ca. 0.5-0.7 at $355 \mathrm{~nm}$. Samples were pumped with the third harmonic of a Q-switched Nd:YAG at $5 \mathrm{~Hz}(2-3 \mathrm{~mJ}$ per pulse and $5 \mathrm{~ns}$ pulse width). Samples were probed at $90^{\circ}$ with a pulsed $75 \mathrm{~W} \mathrm{X}$ arc lamp. Probe light was focused on an ISA monochromator, detected using a Hamamatsu R955 PMT and digitized with a Tetronix DPO40332 digital oscilloscope (350 MHz, 2.5GS s${ }^{-1}$ ). For emission lifetime measurements, the same set up was used with dilute samples. $77 \mathrm{~K}$ spectra were collected in dilute butyronitrile glasses with $5 \mathrm{~nm}$ resolution. Kinetic traces are the average of 16 or 32 shots per wavelength for excited state or emission experiments. Stern-Volmer quenching experiments were performed by titrating with $\mathrm{Et}_{3} \mathrm{~N}$ up to $8 \mathrm{mM}$. Spectra of $1 \mathrm{e}^{-}$reduced species were measured in the presence of $2 \mathrm{mM}$ $\mathrm{Et}_{3} \mathrm{~N}$. Samples were used for a maximum of 5 data points ( 8 laser shots each) before exchanging for a fresh sample due to the irreversible quenching reaction. Solution phase emission spectra were collected using optically dilute solutions with absorptivities at $\lambda_{\text {exc }}$ $<0.2$. Quantum yields of emission in Ar-saturated $\mathrm{CH}_{3} \mathrm{CN}$ were determined by using 
$\left[\mathrm{Ru}(\mathrm{bpy})_{3}\right] \mathrm{Cl}_{2}$ in air saturated $\mathrm{H}_{2} \mathrm{O}$ as the reference $\left(\Phi_{\text {ref }}=0.028\right)^{27}$ using the equation $\Phi_{\text {em }}=\Phi_{\text {ref }}\left(I_{\mathrm{s}} / I_{\text {ref }}\right)\left(\mathrm{A}_{\text {ref }} / \mathrm{A}_{\mathrm{s}}\right)\left(\eta_{\mathrm{s}}^{2} / \eta_{\text {ref }}^{2}\right)$ in which $I$ is the integrated intensity, $\mathrm{A}$ is the absorbance at the excitation wavelength, and $n$ is the refractive index of the solvent.

The redox potentials of the complexes were measured in $\mathrm{CH}_{3} \mathrm{CN}$ solution under $\mathrm{Ar}$ and $\mathrm{CO}_{2}$ (to saturation with $100 \% \mathrm{CO}_{2}: 0.28 \mathrm{M}$ ) containing $0.1 \mathrm{M} \mathrm{Bu}_{4} \mathrm{NPF}_{6}$ using cyclic voltammetry $(\mathrm{CV})$ or Osteryoung square wave voltammetry (OSWV) with a BASi Epsilon potentiostat and a three-electrode configuration with a glassy-carbon disk $(3 \mathrm{~mm})$ working electrode, a $\mathrm{Ag} / \mathrm{AgCl}$ reference electrode and a $\mathrm{Pt}$ wire counter electrode. The reference electrode was calibrated internally using ferrocene and data are reported vs $\mathrm{SCE}$ in $\mathrm{CH}_{3} \mathrm{CN}\left(\mathrm{Fc}^{+/ 0}=0.40 \mathrm{~V} \text { vs } \mathrm{SCE}\right)^{28}$. Sodium reduction was performed in a homemade air tight vessel equipped with a quartz spectrophotometric cell separated by a fine glass frit from a second compartment containing $0.5 \% \mathrm{Na}$ in $\mathrm{Hg}$. Samples were prepared under high vacuum with vacuum-distilled $\mathrm{CH}_{3} \mathrm{CN}$ and were reduced gradually by introducing small portions to the amalgam chamber.

Photocatalytic reactions were carried out in $12 \mathrm{~mL}$ test tubes containing $4.9 \mathrm{~mL}$ of $\mathrm{CO}_{2}$ saturated 5:1 (v/v) $\mathrm{CH}_{3} \mathrm{CN} / \mathrm{TEOA}$ solution with 0.6-0.7 $\mathrm{mM} \mathrm{Ir}$ complex. The solution was irradiated with a $150 \mathrm{~W}$ Xe lamp filtered through $\mathrm{Cu}\left(\mathrm{SO}_{4}\right)$ and a $400 \mathrm{~nm}$ low pass filter. Turnover numbers are the average of two trials with an uncertainty of \pm 1 . Quantum yields of photoproducts were measured by irradiating a solution of the photocatalyst with a monochromatic $405 \mathrm{~nm}$ diode laser with a $91 \mathrm{~mW}$ output in a lightshielding box for 30 minutes. Reported values are the average of two experiments and are reported as mol $\mathrm{CO}$ or $\mathrm{mol} \mathrm{H}_{2}$ per mol of photons/2. Bulk electrolysis experiments were performed in an air-tight two-compartment cell separating a mercury pool working electrode from a Pt mesh counter electrodes by a glass frit. A silver wire pseudo reference was placed as close as possible to the $\mathrm{Hg}$ and $\mathrm{CVs}$ were recorded on glassy carbon prior to electrolysis on $\mathrm{Hg}$. Gaseous products were analyzed by a TCD detector on an Agilent $6890 \mathrm{~N}$ GC with HP-MOLSIV $(30 \mathrm{~m} \times 0.32 \mathrm{~mm} \times 1.5 \mu \mathrm{m})$ and GS-CARBON-PLOT $(15$ $\mathrm{m} \times 0.32 \mathrm{~mm} \times 1.5 \mu \mathrm{m})$ columns. The $\mathrm{CO}$ was quantified via a methanizer using a FID detector. The formate in the solution was analyzed by two ways using ${ }^{1} \mathrm{H}$ NMR: (1) by basifying the electrolyzed solution with $\mathrm{NaOD}$ in $\mathrm{D}_{2} \mathrm{O}$ (2-3 drops), evaporating the $\mathrm{CH}_{3} \mathrm{CN}$, dissolving the sample in $1 \mathrm{~mL} \mathrm{D}_{2} \mathrm{O}$, filtering through a syringe filter to remove $\mathrm{Bu}_{4} \mathrm{NPF}_{6}$ and adding 1,4 dimethylpyridinium iodide in $\mathrm{D}_{2} \mathrm{O}$ as the standard; and (2) by transferring the $\mathrm{CH}_{3} \mathrm{CN}$ solution after electrolysis to a NMR tube and adding a standard solution of 3,5-dimethoxybenzaldehyde in $\mathrm{CD}_{3} \mathrm{CN}$ for integration and for a lock signal. Both methods gave roughly the same quantification. Faradaic efficiencies are the average of two trials.

Collection of of X-ray data and refinement of the structure. Single crystals of $[\operatorname{Ir}(\mathrm{L} 3)($ ppy $) \mathrm{Cl}] \cdot \mathrm{NCCH}_{3}$ suitable for X-ray crystallographic analysis were prepared by slow diffusion of diethyl ether to the NMR sample in $\mathrm{CD}_{3} \mathrm{CN}$ and were mounted on the end of a glass fibers. Data was collected with a Bruker Kappa Apex II diffractometer. Data collected at $200 \mathrm{~K}$ indicated monoclinic symmetry and systematic absences indicating space group $P 2{ }_{1} / n$ which was used for the solution and refinement of the structure. The structure was solved ${ }^{29}$ by direct methods. In the least-squares refinement, ${ }^{29}$ anisotropic temperature parameters were used for all the non-hydrogen atoms. Hydrogen 
atoms were placed at calculated positions and allowed to "ride" on the atom to which they were attached. The isotropic thermal parameters for the hydrogen atoms were determined from the atom to which they are attached. The data were corrected for absorption using the multi-scan method (SADABS). ${ }^{30}$ The crystallographic data were deposited in the Cambridge Crystallographic Data Center (CCDC 1510301).

Computational Methods. All geometries were fully optimized at the M06 level of density functional theory ${ }^{31}$ with the SMD continuum solvation model $^{32}$ for acetonitrile as solvent using the Stuttgart $[8 \mathrm{~s} 7 \mathrm{p} 6 \mathrm{~d} 2 \mathrm{f} \mid$ 6s5p3d2f] ECP60MWB contracted pseudopotential basis set ${ }^{33}$ on $\operatorname{Ir}([8 \mathrm{~s} 7 \mathrm{p} 6 \mathrm{~d} 2 \mathrm{f} \mid 6 \mathrm{~s} 5 \mathrm{p} 3 \mathrm{~d} 2 \mathrm{f}]$ ECP28MWB basis set for Ru) and the $6-31 \mathrm{G}(\mathrm{d})$ basis set on all other atoms. ${ }^{34}$ Non-analytical integrals were evaluated using the integral=grid=ultrafine option as implemented in the Gaussian 09 software package. ${ }^{35}$ The nature of all stationary points was verified by analytic computation of vibrational frequencies, which were also used for the computation of zero-point vibrational energies and molecular partition functions (with all frequencies below 50 $\mathrm{cm}^{-1}$ replaced by $50 \mathrm{~cm}^{-1}$ when computing free energies). Partition functions were used in the computation of $298 \mathrm{~K}$ thermal contributions to free energy employing the usual ideal-gas, rigid-rotator, harmonic oscillator approximation. ${ }^{36}$ Free-energy contributions were added to single-point M06 electronic energies computed with the SDD basis set on Ir and the $6-311++\mathrm{G}(2 \mathrm{df}, \mathrm{p})$ basis set on all other atoms to arrive at final, composite free energies. Standard reduction potentials were calculated for various possible redox couples to assess the energetic accessibility of different intermediates at various oxidation states. For a redox reaction of the form

$$
O_{(\text {soln })}+n e_{(g)}^{-} \rightarrow R_{(\text {soln })}
$$

where $O$ and $R$ denote the oxidized and reduced states of the redox couple, respectively, and $n$ is the number of electrons involved in redox reaction, the reduction potential $E_{O R}^{o}$ relative to SCE was computed as

$$
E_{O R}^{o}=-\Delta G_{O R}^{o} / n F-\Delta E_{r e f}^{o}
$$

Where $\Delta G_{O R}^{o}$ is the free energy change associated with equation 2 (using Boltzmann statistics for the electron) and $\Delta E_{r e f}^{o}$ is taken as $-4.422 \mathrm{~V}$, which is required for the conversion of calculated $E_{O R}^{o}$ relative to the vacuum level to $E_{O R}^{o}$ versus the saturated calomel electrode (SCE) in acetonitrile.

\section{Acknowledgement}

We thank Dr. Javier Concepcion for fruitful discussions regarding the synthesis of Ir complexes. The work carried out at Brookhaven National Laboratory was supported by the U.S. Department of Energy, Office of Science, Division of Chemical Sciences, Geosciences, \& Biosciences, Office of Basic Energy Sciences under contract DESC00112704. T.S. thanks the Japan Public-Private Partnership Student Study Abroad Program "Tobitate! Young Ambassador Program".

\section{References}


1. E. S. Wiedner, M. B. Chambers, C. L. Pitman, R. M. Bullock, A. J. M. Miller and A. M. Appel, Chem. Rev., 2016, 116, 8655-8692.

2. W.-H. Wang, Y. Himeda, J. T. Muckerman, G. F. Manbeck and E. Fujita, Chem. Rev., 2015, 115, 12936-12973.

3. W. W. Ellis, A. Miedaner, C. J. Curtis, D. H. Gibson and D. L. DuBois, J. Am. Chem. Soc., 2002, 124, 1926-1932.

4. J. T. Muckerman, P. Achord, C. Creutz, D. E. Polyansky and E. Fujita, Proc. Nat. Acad. Sci. U.S.A., 2012, 109, 15657-15662.

5. C. Creutz and M. H. Chou, J. Am. Chem. Soc., 2007, 129, 10108-10109.

6. C. Creutz and M. H. Chou, J. Am. Chem. Soc., 2009, 131, 2794-2795.

7. Y. Matsubara, E. Fujita, M. D. Doherty, J. T. Muckerman and C. Creutz, J. Am. Chem. Soc., 2012, 134, 15743-15757.

8. C. Tsay, B. N. Livesay, S. Ruelas and J. Y. Yang, J. Am. Chem. Soc., 2015, 137, 14114-14121.

9. S. Sato, T. Morikawa, S. Saeki, T. Kajino and T. Motohiro, Angew. Chem. Int. Ed., 2010, 49, 5101-5105.

10. K. Garg, Y. Matsubara, M. Z. Ertem, A. Lewandowska-Andralojc, S. Sato, D. J. Szalda, J. T. Muckerman and E. Fujita, Angew. Chem. Int. Ed., 2015, 54, 14128-14132.

11. S. Sato, T. Morikawa, T. Kajino and O. Ishitani, Angew. Chem. Int. Ed., 2013, 52, 988-992.

12. S. Obara, M. Itabashi, F. Okuda, S. Tamaki, Y. Tanabe, Y. Ishii, K. Nozaki and M.-a. Haga, Inorg. Chem., 2006, 45, 8907-8921.

13. D. N. Chirdon, W. J. Transue, H. N. Kagalwala, A. Kaur, A. B. Maurer, T. Pintauer and S. Bernhard, Inorg. Chem., 2014, 53, 1487-1499.

14. J. A. Porras, I. N. Mills, W. J. Transue and S. Bernhard, J. Am. Chem. Soc., 2016, 138, 9460 9472 .

15. D. N. Chirdon, C. E. McCusker, F. N. Castellano and S. Bernhard, Inorg. Chem., 2013, 52, 8795-8804.

16. A. J. Morris, G. J. Meyer and E. Fujita, Acc. Chem. Res., 2009, 42, 1983-1994.

17. C. Costentin, S. Drouet, M. Robert and J.-M. Saveant, J. Am. Chem. Soc., 2012, 134, $11235-$ 11242.

18. A. Auffrant, A. Barbieri, F. Barigelletti, J. P. Collin, L. Flamigni, C. Sabatini and J. P. Sauvage, Inorg. Chem., 2006, 45, 10990-10997.

19. E. Shikhova, E. O. Danilov, S. Kinayyigit, I. E. Pomestchenko, A. D. Tregubov, F. Camerel, P. Retailleau, R. Ziessel and F. N. Castellano, Inorg. Chem., 2007, 46, 3038-3048.

20. K. Ichimura, T. Kobayashi, K. A. King and R. J. Watts, J. Phys. Chem., 1987, 91, 6104-6106.

21. L. L. Duan, G. F. Manbeck, M. Kowalczyk, D. J. Szalda, J. T. Muckerman, Y. Himeda and E. Fujita, Inorg. Chem., 2016, 55, 4582-4594.

22. T. Yutaka, S. Obara, S. Ogawa, K. Nozaki, N. Ikeda, T. Ohno, Y. Ishii, K. Sakai and M.-a. Haga, Inorg. Chem., 2005, 44, 4737-4746.

23. S. Kawamorita, T. Miyazaki, H. Ohmiya, T. Iwai and M. Sawamura, J. Am. Chem. Soc., 2011, 133, 19310-19313.

24. M. Z. Chen and G. C. Micalizio, J. Am. Chem. Soc., 2012, 134, 1352-1356.

25. R. F. Carina, A. F. Williams and G. Bernardinelli, Inorg. Chem., 2001, 40, 1826-1832.

26. A. W. Addison and P. J. Burke, J. Heterocycl. Chem., 1981, 18, 803-805.

27. K. Nakamaru, Bull. Chem. Soc. Jpn., 1982, 55, 2697-2705.

28. N. G. Connelly and W. E. Geiger, Chem. Rev., 1996, 96, 877-910.

29. G. M. Sheldrick; 5 ed.; Siemens Analytical Instruments Inc.: Madison WI, 1994.

30. Sheldrick; Bruker AXS Inc.: 2007.

31. Y. Zhao and D. G. Truhlar, Theo. Chem. Acc., 2008, 120, 215-241.

32. A. V. Marenich, C. J. Cramer and D. G. Truhlar, J. Phys. Chem. B, 2009, 113, 6378-6396.

33. D. Andrae, U. Haussermann, M. Dolg, H. Stoll and H. Preuss, Theo. Chim. Acta, 1990, 77, 123-141. 
34. W. J. Hehre, L. Radom, P. v. R. Schleyer and J. A. Pople Ab Initio Molecular Orbital Theory; Wiley: New York, 1986.

35. M. J. Frisch, G. W. Trucks, H. B. Schlegel, G. E. Scuseria, M. A. Robb, J. R. Cheeseman, G. Scalmani, V. Barone, B. Mennucci, G. A. Petersson, H. Nakatsuji, M. Caricato, X. Li, H. P. Hratchian, A. F. Izmaylov, J. Bloino, G. Zheng, J. L. Sonnenberg, M. Hada, M. Ehara, K. Toyota, R. Fukuda, J. Hasegawa, M. Ishida, T. Nakajima, Y. Honda, O. Kitao, H. Nakai, T. Vreven, J. A. Montgomery, J. E. Peralta, F. Ogliaro, M. Bearpark, J. J. Heyd, E. Brothers, K. N. Kudin, V. N. Staroverov, R. Kobayashi, J. Normand, K. Raghavachari, A. Rendell, J. C. Burant, S. S. Iyengar, J. Tomasi, M. Cossi, N. Rega, J. M. Millam, M. Klene, J. E. Knox, J. B. Cross, V. Bakken, C. Adamo, J. Jaramillo, R. Gomperts, R. E. Stratmann, O. Yazyev, A. J. Austin, R. Cammi, C. Pomelli, J. W. Ochterski, R. L. Martin, K. Morokuma, V. G. Zakrzewski, G. A. Voth, P. Salvador, J. J. Dannenberg, S. Dapprich, A. D. Daniels, Ö. Farkas, J. B. Foresman, J. V. Ortiz, J. Cioslowski and D. J. Fox Gaussian 09, Revision A.02; Gaussian, Inc.: Wallingford, CT, 2010.

36. C. J. Cramer Essentials of Computational Chemistry: Theories and Models; 2nd ed.; John Wiley \& Sons: Chichester, 2004. 